\title{
Open Dumping of Muncipal Solid Waste and its Hazardous Impact on Soil and Ground Water
}

\author{
Nandini Kad ${ }^{1}$, Bhakti Kale ${ }^{2}$, Devyami Kamble ${ }^{3}$, Fatima Khwaja ${ }^{4}$ \\ Civil engineering department of \\ Deogiri institute of engineering and management studies Aurangabad, India
}

\begin{abstract}
Open dumping sites which generates serious health risks. The main aim of this paper is to shoe the effects of that open dumping on ground water resource, soil quality. It was observed that the people living in this area have poor health like allergy, asthma, skin irritation and other gastro intestinal diseases. The focus of this study is to assess the contribution of open dumping in soil contamination, water contamination and its effects on human.
\end{abstract}

Surface soil sample were collected from open dumping site Naregaon and nearby area. Significant modifications were observed in the soil properties of dumping sites. Soil at the disposal site shows high pH Electrical conductivity. Various heavy metal concentration i.e. Zinc ( $\mathrm{Zn})$, copper $(\mathrm{Cu})$, Iron (Fe), manganese (mg).

Keywords:- Solidwaste, Soil Deteortion, Ground Water.

\section{INTODUCTION}

The energy recovery from MSW may repay for energy demand and thus to minimize the use of conventional energy sources during the landfill process the municipal waste has to gone through a certain stages like collection, transportation and or segregation leading to variation in quality quantity of waste during final disposal of waste. Inadequate methods adopted for disposal of solid waste are responsible for the serious health concern. The poorly maintained landfill sites are prone to ground water contamination because of leachate production. Open dumping of garbage facilities the breeding for diseases vectors such as files, mosquitoes, cockroaches, rats and other pets.

The study of baseline data of management of solid waste Aurangabad city includes the information about the waste collection, storage, transportation and disposal reveals that, in the Municipal corporation has appointed large number of employs for the management of solid waste, it was found that the solid waste was not disposed scientifically and till the citizens are facing the solid waste problem.

\section{DESCRIPTION OF STUDY AREA}

The dumping sit is located at village Naregaon is situated 6 kilometers outskirts of Aurangabad city. Geographically it is situated at 190 54'15" northern latitude and 750 23'45" eastern longitudes. The disposal site covers an area of about 46 acres approx.

\section{METHODOLOGY}

Based on the focus of this study surface soil sample collected from the depth of 9 inches were collected from the waste disposal site located nagregaon. This site has been specified as an open area which is used for open waste dumping. Soil sample is brought to the laboratory and were prepared for further analyses. They were air dried, sieved and ground.

Many analyses performed in order to study the parameters that evaluated soil quality. Soil sample was estimated for $\mathrm{pH}$ electrical conductivity, zinc, copper, iron in the soil acid digests was measured using atomic adsorption spectrophotometer. Located.

Ground water sample is collected from nearby area. Eight samples collected from subsector area. An analysis were performed in order to study the parameters that evaluated ground water quality each water sample was estimated for Ph Electrical conductivity, chloride, calcium, manganese total hardness, BOD.

\section{RESULT AND DISCUSSION}

\section{A. Effect of solid waste on soil}

\begin{tabular}{|c|c|c|c|c|}
\hline Sr. no. & Parameter & Results & Standard value & Units \\
\hline 1. & $\mathrm{pH}$ & 8.56 & $6.7-7.3$ & $\mathrm{M}$ \\
\hline 2. & Electrical conductivity & 30.75 & $0.5-1$ & $\mathrm{Ms} / \mathrm{cm}$ \\
\hline 3. & Zinc & 12.20 & $0.5-1$ & $\mathrm{Mg} / \mathrm{l}$ \\
\hline 4. & Copper & 28.3 & $2-4$ & $\mathrm{Mg} / \mathrm{l}$ \\
\hline 5. & Iron & 86.4 & $1-2$ & $\mathrm{Mg} / \mathrm{l}$ \\
\hline 6. & Manganese & 70.1 & $\mathrm{Mg} / \mathrm{l}$ \\
\hline
\end{tabular}

Table 1:- soil testing results 
From table 1 it is observed that soil quality get affected because of this open dumping. As per results of the study it became evident that the local resident are aware of different types of diseases that may occurs due to the exposure to certain harmful waste and living near be dumping ground.

\section{B. Effect of solid waste on ground water}

\begin{tabular}{|c|c|c|c|c|c|}
\hline sample & $\mathrm{ph}$ & $\begin{array}{c}\mathrm{EC} \\
\mathrm{Ms} / \mathrm{cm}\end{array}$ & $\begin{array}{c}\mathrm{Cl} \\
\mathrm{Mg} / 1\end{array}$ & $\begin{array}{c}\mathrm{Mg} \\
\mathrm{Mg} / \mathrm{l}\end{array}$ & $\begin{array}{c}\mathrm{Ca} \\
\mathrm{Mg} / 1 \\
\end{array}$ \\
\hline S1 & 9.96 & 2.49 & 7.3 & 16.9 & 6.6 \\
\hline S2 & 10.12 & 2.43 & 21.5 & 16.8 & 5.8 \\
\hline S3 & 9.35 & 2.89 & 9 & 15.1 & 11.3 \\
\hline S4 & 9.57 & 2.56 & 15 & 14.8 & 5.9 \\
\hline S5 & 10.02 & 2.33 & 20.5 & 15.0 & 7 \\
\hline S6 & 8.99 & 3.0 & 9.6 & 16.5 & 8.3 \\
\hline S7 & 9.36 & 1.99 & 14.2 & 14.9 & 5.6 \\
\hline S8 & 10.00 & 2 & 16 & 16.1 & 6.5 \\
\hline
\end{tabular}

Table 2:- ground water testing

\begin{tabular}{|c|c|c|c|c|}
\hline Sample & $\begin{array}{c}\text { Total hardness } \\
\text { Mg/l }\end{array}$ & $\begin{array}{c}\text { Ca } \\
\text { Hardness } \\
\mathrm{Mg} / \mathrm{l}\end{array}$ & $\begin{array}{c}\mathrm{Mg} \\
\text { Hardness } \\
\mathrm{Mg} / \mathrm{l}\end{array}$ & $\begin{array}{c}\text { BOD } \\
\mathrm{Mg} / \mathrm{l}\end{array}$ \\
\hline S1 & 23.5 & 132.09 & 69.56 & 16 \\
\hline S2 & 22.5 & 116.08 & 69.14 & 14 \\
\hline S3 & 22.6 & 226.18 & 62.15 & 15 \\
\hline S4 & 15.1 & 142.50 & 59.66 & 19 \\
\hline S5 & 19.5 & 202.32 & 63.54 & 15.6 \\
\hline S7 & 20.5 & 156.56 & 68.06 & 14.9 \\
\hline S8 & 22.3 & 225.62 & 62.35 & 1.98 \\
\hline
\end{tabular}

Table 3:- Ground water testing

From table 2, 3 it is clear that water is also get contaminated because of unsanitary landfill.

\section{CONCLUSION}

The sites for solid waste dumping to be selected only after proper geo hydrological investigation of area, to avoid percolation of pollutants.

Aurangabad Municipal Corporation is unable to offer the desired level of services with the existing capacity and trend of waste management due to fast increasing population.

The waste generated form residential area comprises the maximum portion of degradable material it reflects that Aurangabad city area suitable for the application of composting techniques.

\section{ACKNOWLEDGMENT}

I would wish to thank my guide and my institute for his valuable and firm suggestion, guidance and constant support throughout this work.

\section{REFERENCES}

[1]. Almgir,M,:Donald,C.Mc:(2005)integrated managemnt and safe disposal of MSW in least devloped asian contouries.

[2]. Amul late and M.B.mule,characterisation and composition study of solid waste from aurangabad city.

[3]. Daniel hoornweg and perinaz bhadatata (2012),a golbal review of solidwaste management .

[4]. Gauri kalawar,rekha tiwari,solid waste management:case study of aurangabd maharashtra. 